\title{
Synthesis and structure of polyunsaturated [10]paracyclophane annulated by two azulene rings
}

\author{
Shigeyasu Kuroda, ${ }^{\text {a, }}$ Yuji Obata, ${ }^{\text {a }}$ Nguyen Chung Thanh, ${ }^{a}$ Ryuta Miyatake, ${ }^{\text {}}$ Yoshikazu Horino, ${ }^{\text {a }}$ and \\ Mitsunori Oda ${ }^{\text {b,* }}$ \\ ${ }^{a}$ Department of Applied Chemistry, Graduate School of Science and Engineering, University of Toyama, \\ Gofuku 3190, Toyama, Japan. 930-8555 \\ ${ }^{\mathrm{b}}$ Department of Chemistry, Faculty of Science, Shinshu University, Asahi 3-1-1, Matsumoto,
} Nagano, Japan 390-8621

\begin{abstract}
The polyunsaturated [10]paracyclophane 4 was synthesized from 1,4-diacetylbenzene by a four-step sequence involving the modified Yasunami azulene synthesis, introduction of two butenone units, and a subsequent McMurry coupling reaction. The crystal structures of $\mathbf{4}$ and the synthetic intermediate 8 was determined by X-ray crystallographic analysis and the results reveal that 1) the benzene ring of $\mathbf{4}$ is distorted as a boat form with relatively small bending angles and 2) the azulene rings of 8 show large out-of-plane deformation along the short azulene molecular axis.
\end{abstract}

Keywords: Cyclophanes; X-ray crystallographic analysis; McMurry coupling; $2 H$-cyclohepta[b]fura-2-one; Azulene

*Corresponding authors: S. Kuroda; Tel./fax.: + 8176445 6819; e-mail: kuro@eng.u-toyama.ac.jp; $\quad$ M. $\quad$ Oda; $\quad$ Tel./fax.: $\quad+\quad 81263 \quad 37$ 3343; e-mail: mituoda@shinshu-u.ac.jp

Unsaturation at the bridge part of cyclophanes ${ }^{1}$ is a challenging subject in cyclophane chemistry. Recent synthesis of highly unsaturated cyclophanes, such as cyclophynes, ${ }^{2}$ has been extensively studied toward carbon-rich aromatics. ${ }^{3}$ We have been interested in polyunsaturation of the bridge part of [10]paracyclophane (1), particularly with a polyvinyl unit, ${ }^{4}$ because of its molecular distortion and $\mathrm{CH}-\pi$ and $\pi-\pi$ interactions between the bridging part and benzene ring. Base on DFT calculations, it is predicted that the all-cis- and cis,trans,cis,trans,cis-isomers, 2 and 3, have a slightly bent benzene ring, and the $\mathrm{CH}-\pi$ interaction in them is possible in $\mathbf{3}$ and $\pi-\pi$ interactions are negligible. ${ }^{5}$ Toward $\mathbf{2}$ or $\mathbf{3}$ as our final goal, we have preliminarily engaged in synthesis of the diazuleno derivative 4 . Herein we describe the synthesis of the cyclophane 4 and also provide $\mathrm{X}$-ray crystallographic analysis of $\mathbf{4}$ and the synthetic intermediate $\mathbf{8}$. 


\section{Chart 1}

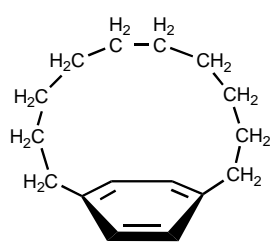

[10]Paracyclophane (1)

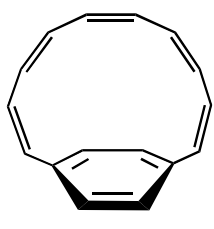

all-cis-Decahydro[10]paracyclophane (2)

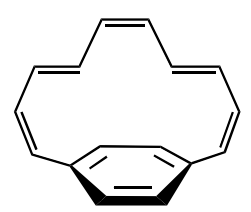

cis, trans, cis, trans, cis Decahydro[10]paracyclophane (3)

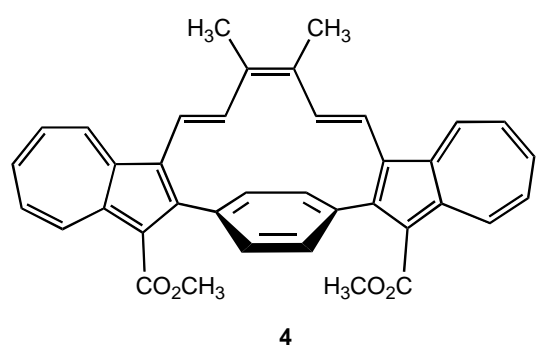

The synthesis of 4 was accomplished as shown in Scheme 1. The azulene skeleton was constructed by the modiefied Yasunami-Takase azulene synthesis. ${ }^{6}$ Bistrimethysilyl enol ether $\mathbf{5}^{7}$ of commercially available 1,4-diacetylbenzene was reacted with 3-methoxycarbonyl-2H-cyclohepta[b]fura-2-one $(\mathbf{6})^{8}$ in refluxing decaline for $4 \mathrm{hr}$ to give 1,4-diazulenobenzene derivative 7 in $10 \%$ yield. ${ }^{9}$ Double elongation of a four-carbon unit in 7 was achieved by electrophilic substitution with 4,4-dimethoxybutan-2-one under acidic conditions and subsequent elimination of methanol under basic conditions ${ }^{10}$ to afford $\mathbf{8}$, having all required carbons for $\mathbf{4}$, in $28 \%$ yield. Stereochemistry of the formed C-C double bonds in $\mathbf{8}$ was confirmed as trans by the vicinal coupling constant in the NMR spectrum. Final intramolecular McMurry coupling ${ }^{11}$ of $\mathbf{8}$ using titanium trichloride and lithium aluminum hydride in refluxing THF provided compound 4 in $20 \%$ yield. ${ }^{12,13}$

\section{Scheme 1}

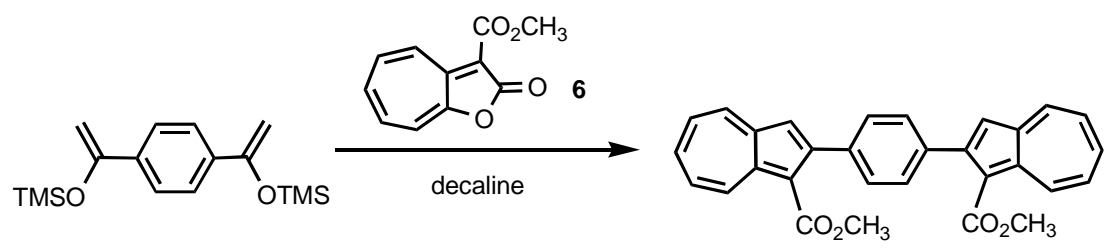

7

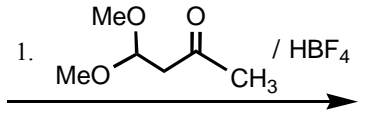

2. $\mathrm{NaHCO}_{3}$<smiles>CC(=O)C=Cc1c2cccccc-2c(C(C)=O)c1-c1ccc(-c2c(C=CC(C)=O)c3cccccc-3c2C(C)=O)cc1</smiles>

$\mathrm{TiCl}_{3} / \mathrm{LiAlH}_{4}$ 
The cyclophane 4 was obtained as stable, dark green crystals with a relatively high melting point. In the ${ }^{1} \mathrm{H}$ NMR spectrum of 4 in $\mathrm{CDCl}_{3}$, the ethenyl protons in the dimethylhexatrienyl bridge appear at 6.62 (Ha in Fig. 1) and $6.92(\mathrm{Hb})$ ppm with a coupling constant of $16.0 \mathrm{~Hz}$, which indicates that the stereochemistry of the $\mathrm{C}-\mathrm{C}$ double bonds attached to the azulene ring remains as trans. Assignment of the ethenyl protons was confirmed by the results of the NOE experiments shown in Fig. 1. Their chemical shifts were deshielded slightly compared with those of $\mathbf{8}$. Since proton chemical shifts of the azulene and benzene rings are similar for $\mathbf{4 , 7}$, and $\mathbf{8}$, those rings do not interact with each other in these compounds, suggesting interplanar distortion between planes of those rings (vide infra). In the UV-visible spectrum of $\mathbf{4}$, the long wave absorption maximum, corresponding to the $\pi-\pi^{*}$ excitation of the azulene part, exhibited only slight bathochromic shift compared with that of $\mathbf{8}$.

Figure 1. Results of NOE experiments of 4.

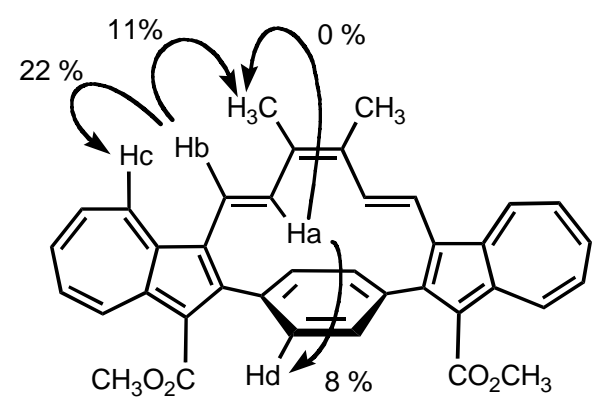

The crystal structures of $\mathbf{4}$ and $\mathbf{8}$ were determined by X-ray diffraction analysis and are shown in Figs. 2 and 3. The interplanar angle between the benzene and the azulene rings ring in 4 is $70^{\circ}$. Whereas the benzene ring of $\mathbf{8}$ is almost planar, the benzene ring of $\mathbf{4}$ is non-planar, having a shallow boat form, as expected. The bending angles, shown in Fig. 4, of $\mathbf{4}$ are smaller than those of tetradehydro[2.2]paracyclophane and are comparable to values of the calculated structures of 2 and 3. ${ }^{14}$ The distance of the olefinic Ha proton and the nearest benzene carbon atom is $2.51 \AA$, evidence of the $\mathrm{CH}-\pi$ interaction between them. It should be noted that the azulene ring of $\mathbf{8}$ shows out-of-plane deformation along the short azulene molecular axis. We recently reported such a deformation in 1,3-diarylazulenes, 10 and 11. ${ }^{15}$ Twisted angles ${ }^{16}$ for C1-C3 of $\mathbf{8}$ are greater than those of $\mathbf{1 0}$ and $\mathbf{1 1}$ (Table 1), indicating that $\mathbf{8}$ has the greatest deformation so far. 
Figure 2. ORTEP drawings and crystal packing of $\mathbf{4}$
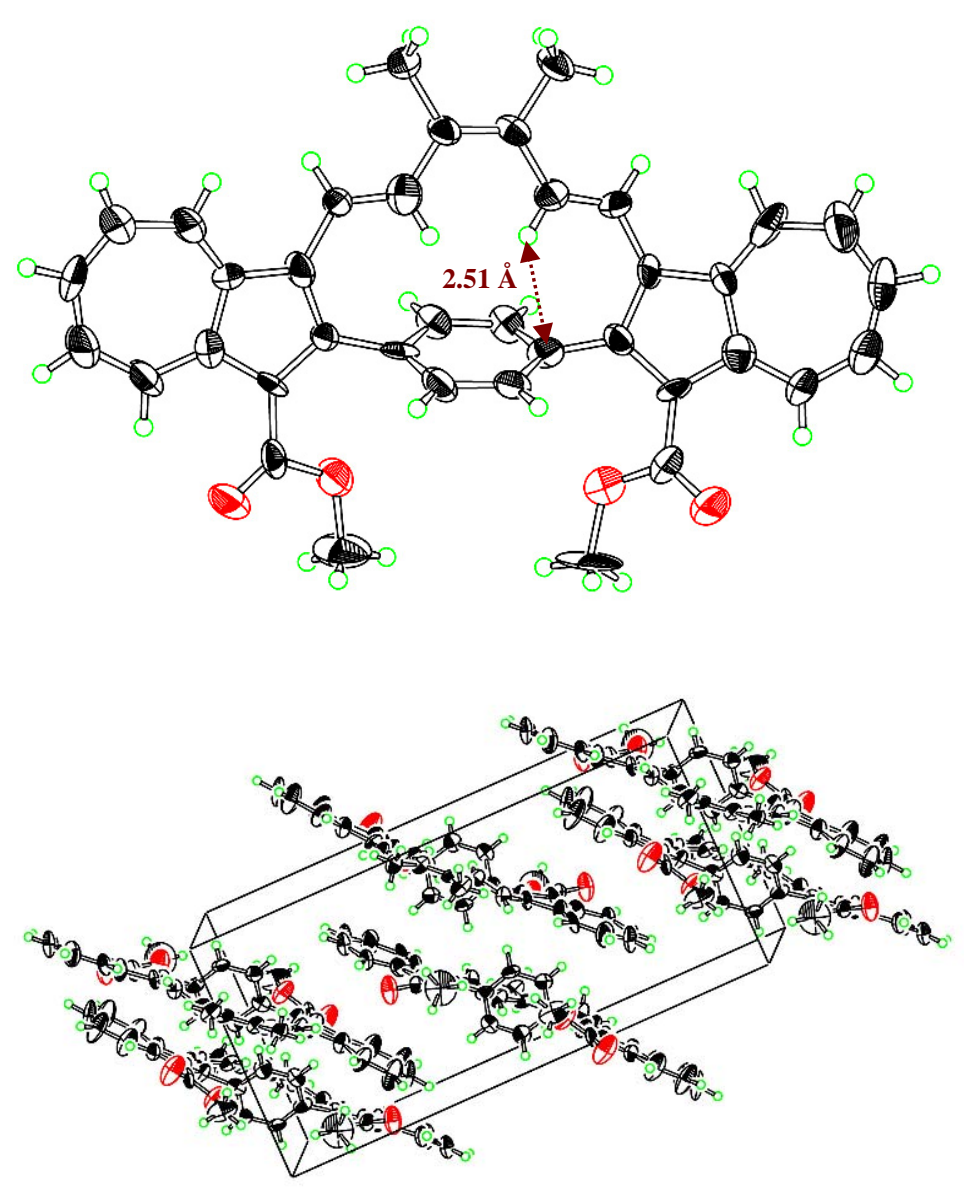

Figure 3. ORTEP drawings of $\mathbf{8}$ with our numbering

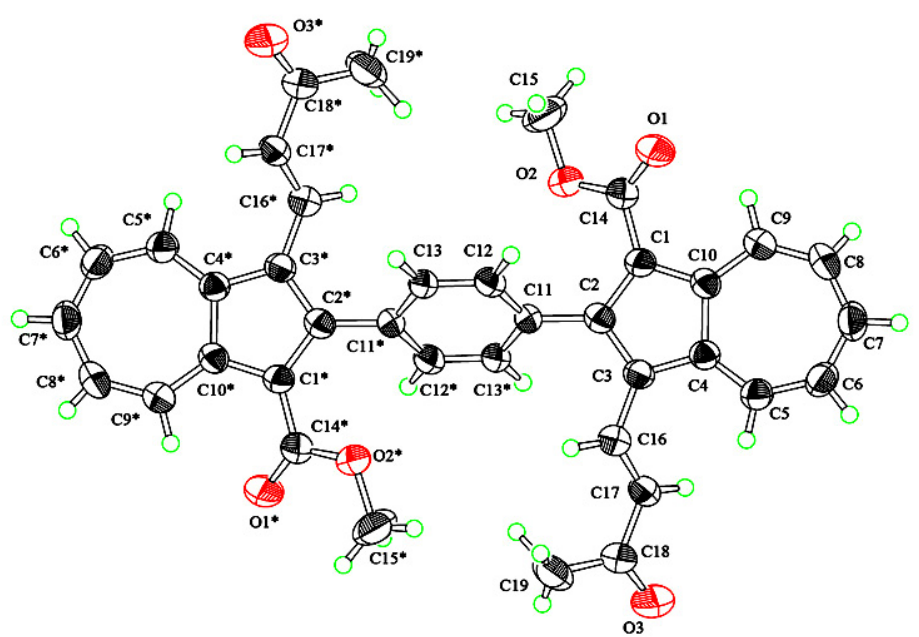


Figure 4. Bending angles of 4

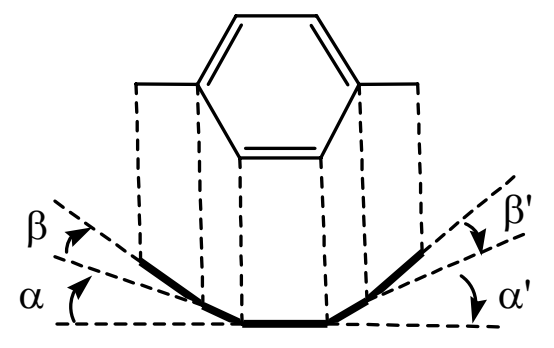

$$
\begin{gathered}
\alpha=4.7^{\circ}, \beta=7.3^{\circ} \\
\alpha^{\prime}=4.0^{\circ}, \beta^{\prime}=6.9^{\circ}
\end{gathered}
$$

Chart 2. Structures of 1,3-diarylazulenes $\mathbf{1 0}$ and $\mathbf{1 1}$ with our numbering

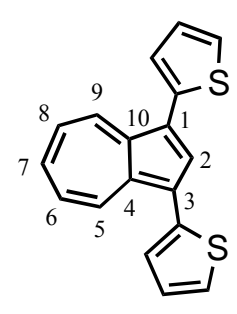

10

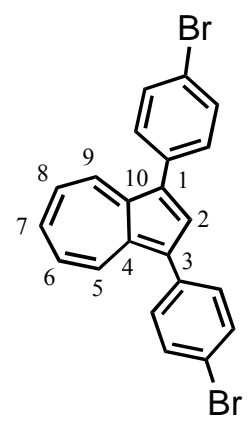

11

Table 1. Out-of-plane deformation of crystal structures of $\mathbf{8}, \mathbf{1 0}$, and $\mathbf{1 1}$ as shown by twist angles.

\begin{tabular}{cccc}
\hline Compound & \multicolumn{3}{c}{ Twisted angles (in degree) for C1-C3 } \\
\cline { 2 - 4 } & $\mathrm{C}^{2}-\mathrm{C} 10^{\mathrm{a}}$ & $\mathrm{C} 5-\mathrm{C} 9^{\mathrm{a}}$ & $\mathrm{C6}-\mathrm{C} 8^{\mathrm{a}}$ \\
\hline $\mathbf{8}$ & $\mathbf{2 . 2 5}$ & $\mathbf{9 . 0 2}$ & $\mathbf{1 3 . 3 0}$ \\
$\mathbf{1 0}^{\mathrm{b}}$ & 1.39 & 4.80 & 6.56 \\
$\mathbf{1 1}^{\mathrm{b}}$ & 3.16 & 7.27 & 9.69 \\
\hline
\end{tabular}

${ }^{a}$ Numbering is shown in Fig. 3 and Chart 2. ${ }^{\mathrm{b}}$ Taken from ref 15(b)

In summary, we constructed the fully unsaturated [10[paracyclophane framework of $\mathbf{3}$ annulated by two azulene rings by four steps from the commercially available compound. The crystal structure of 4 suggests that the benzene ring has a shallow boat form and also provides evidence of a $\mathrm{CH}-\pi$ interaction. In addition, it was found that the crystal structure of the synthetic intermediate 8 showed another example of the azulene ring distortion along its short azulene molecular axis with large twisted angles.

\section{Acknowledgements}

We thank Mr Taihei Kano at University of Toyama for his technical assistance. 


\section{References and Notes}

1. For books of cyclophanes, see; (a) Diederich, F. Cyclophanes, 1991, The Royal Society of Chemistry, Cambridge, UK; (b) Vögtle, F. Cyclophane Chemistry, 1993, Jones, P. R. (Trans.); John Wiley \& Sons, New York; (c) Takemura, H. (Ed.), Cyclophane Chemistry for the 21st Century, 2002, Research Signpost, Trivandrum; (d) Modern Cyclophane Chemistry, Gleiter, R.; Hopf, H. (Eds); 2004, Wiley-VCH, Weinheim.

2. Tobe, Y.; Sonoda, M. Cyclophynes, Ch1, 2004, pp1-40, in ref. 1(d).

3. Haley, M. M.; Tykwinski R. R. (Eds), Carbon-Rich Compounds, 2006, Wiley-VCH, Weinheim.

4. For an elegant generation of unsaturated [4]paracyclophane, see; Tsuji, T.; Nishida, S. J. Am. Chem. Soc. 1989, 111, 368-369.

5. DFT calculations were conducted at B3LYP/6-31G(d) level of theory by using the Mulliken (ver. 2.0.0, IBM Inc.) program.

6. For the original azulene synthesis from enamines and $2 H$-cyclohepta[b]fura-2-ones by Yasunami and Takase, see; Yang, P.-W.; Yasunami, M.; Takase, K. Tetrahedron Lett. 1971, 4275-4278. Yasunami et al. reported that azulenes can be synthesized from silylenol ethers with $2 \mathrm{H}$-cyclohepta[b]fura-2-ones; The results were presented in the 84th Annual Meeting of Chemical Society; Yasunami, M.; Sato, T.; Watanabe, T. 2004, p1409 (3 PC-061).

7. (a) Posner, G. H.; Ploypradith, P.; Parker, M. H.; O'Dowd, H.; Woo, S.-H.; Northrop, J.; Krasavin, M.; Dolan, P.; Kensler, T. W.; Xie, S.; Shapiro, T. A. J. Med. Chem. 1999, 42, 4275-4280; (b) Posner, G. H.; Northrop, J.; Paik, I.-H.; Borstnik, K.; Dolan, P.; Kensler, T. W.; Xie, S.; Shapiro, T. A. Bioorg. Med. Chem. 2002, 10, 227-232.

8. Yang, P.-W.; Lin, L.-C. Huaxue 1973, 1, 1-6; Fujimori, K.; Fujita, T.; Yamane, K.; Yasunami, M.; Takase, K. Chem. Lett. 1983, 11, 1721-4; Nozoe, T.; Wakabayashi, H.; Ishikawa, S.; Wu, C. P.; Yang, P. W. Heterocycles 1990, 31, 17-22.

9. The monoazuleno product was obtained as a major product in $30 \%$ yield. So far the best yield of 4 is $10 \%$ despite several efforts for improving the yield under various conditions.

10. Hafner, K.; Pelster, H.; Schneider, J. Leibigs Ann. Chem. 1961, 650, 62-80.

11. (a) McMurry, J. E. Acc. Chem. Res. 1983, 16, 405-411; (b) McMurry, J. E. Chem. Rev. 1989, 89, 1513-1524; (c) Lenoir, D. Synthesis 1989, 883-897; (d) Fuerstner, A.; Bogdanovic, B. Angew. Chem., Int. Ed. Engl. 1996, 35, 2443-2469; (e) Furstner, A. Pure \& Appl. Chem. 1998, 70, 1071-1076; (f) Furstner, A. In Transition Metals for Organic Synthesis, Beller, M.; Bolm, C. (Eds.); 2004, 1, pp449-468, Wiley-VCH, Weinheim; (h) Ladipo, F. T. Curr. Org. Chem. 2006, 10, 965-980.

12. All new compounds were characterized by spectral and combustion analyses. Selected data of new compounds are as follows; 4: Dark green prisms, mp $=289-292{ }^{\circ} \mathrm{C},{ }^{1} \mathrm{H}$ NMR $\left(\mathrm{CDCl}_{3}\right) \delta=9.58(\mathrm{~d}, J=10.0 \mathrm{~Hz}, 2 \mathrm{H}), 8.84(\mathrm{~d}, J=10.0 \mathrm{~Hz}, 2 \mathrm{H}), 7.75(\mathrm{t}, J=10.0 \mathrm{~Hz}, 2 \mathrm{H})$, 
$7.50(\mathrm{t}, J=10.0 \mathrm{~Hz}, 2 \mathrm{H}), 7.47(\mathrm{~s}, 4 \mathrm{H}), 7.41(\mathrm{t}, J=10.0 \mathrm{~Hz}, 2 \mathrm{H}), 6.92(\mathrm{~d}, J=16.0 \mathrm{~Hz}, 2 \mathrm{H})$, $6.62(\mathrm{~d}, J=16.0 \mathrm{~Hz}, 2 \mathrm{H}), 3.78(\mathrm{~s}, 6 \mathrm{H}), 2.00(\mathrm{~s}, 6 \mathrm{H}) \mathrm{ppm} ;{ }^{13} \mathrm{C} \mathrm{NMR}\left(\mathrm{CDCl}_{3}\right) \delta=166.3$, $152.1,141.7,139.6,139.3,139.2,137.7,134.7,132.4,131.1,128.4,128.3,126.6,126.4$, $116.5,115.9,50.8,14.6 \mathrm{ppm}$; IR (KBr) $v_{\max }=1681 \mathrm{~s}, 1390 \mathrm{~s}, 1166 \mathrm{~s} \mathrm{~cm}^{-1}$; UV $\left(\mathrm{CH}_{2} \mathrm{Cl}_{2}\right) \lambda_{\max }$ $=230 \mathrm{sh}(\log \varepsilon=4.46), 238$ (4.52), 295 (4.66), 320sh (4.46), 357 (4.36), 450 (4.34), 611 (3.00) nm. 7: Red prisms, $\mathrm{mp}=224-226{ }^{\circ} \mathrm{C},{ }^{1} \mathrm{H} \mathrm{NMR}\left(\mathrm{CDCl}_{3}\right) \delta=9.56(\mathrm{~d}, J=10.0 \mathrm{~Hz}, 2 \mathrm{H})$, $8.87(\mathrm{~d}, J=10.0 \mathrm{~Hz}, 2 \mathrm{H}), 7.95(\mathrm{~d}, J=16.0 \mathrm{~Hz}, 2 \mathrm{H}), 7.91(\mathrm{t}, J=10.0 \mathrm{~Hz}, 2 \mathrm{H}), 7.68$ (t, $J=$ $10.0 \mathrm{~Hz}, 2 \mathrm{H}), 7.64$ (t, $J=10.0 \mathrm{~Hz}, 2 \mathrm{H}), 7.48(\mathrm{~s}, 4 \mathrm{H}), 6.52$ (d, $J=16.0 \mathrm{~Hz}, 2 \mathrm{H}), 3.79$ (s, 6H), $2.32(\mathrm{~s}, 6 \mathrm{H}) \mathrm{ppm} ;{ }^{13} \mathrm{C} \mathrm{NMR}\left(\mathrm{CDCl}_{3}\right) \delta=198.3,166.0,154.0,143.1,141.0,140.1,138.4$, 136.7, 136.3, 136.2, 129.9, 129.1, 128.9, 128.0, 122.4, 117.5, 51.2, 27.6 ppm; IR (KBr) $v_{\max }=1688 \mathrm{~s}, 1650 \mathrm{~s}, 1219 \mathrm{~s} \mathrm{~cm}^{-1} ; \mathrm{UV}\left(\mathrm{CH}_{2} \mathrm{Cl}_{2}\right) \lambda_{\max }=229 \mathrm{sh}(\log \varepsilon=4.60), 249$ (4.71), 324 (4.91), 344 (4.93), 395sh (4.48), 414sh (4.34), 557 (3.12) 594sh (3.0), 644sh (2.67) nm. 8: Violet prisms, $\mathrm{mp}=263-265{ }^{\circ} \mathrm{C},{ }^{1} \mathrm{H}$ NMR $\left(\mathrm{CDCl}_{3}\right) \delta=9.42(\mathrm{~d}, J=10.0 \mathrm{~Hz}, 2 \mathrm{H}), 8.44(\mathrm{~d}, J$ $=10.0 \mathrm{~Hz}, 2 \mathrm{H}), 7.77(\mathrm{t}, J=10.0 \mathrm{~Hz}, 2 \mathrm{H}), 7.68(\mathrm{~s}, 4 \mathrm{H}), 7.55(\mathrm{t}, J=10.0 \mathrm{~Hz}, 2 \mathrm{H}), 7.45(\mathrm{t}, J=$ $10.0 \mathrm{~Hz}, 2 \mathrm{H}), 7.44(\mathrm{~s}, J=2 \mathrm{H}), 3.84(\mathrm{~s}, 6 \mathrm{H}) \mathrm{ppm} ;{ }^{13} \mathrm{C} \mathrm{NMR}\left(\mathrm{CDCl}_{3}\right) \delta=166.7,153.1$, $142.7,142.1,138.3,137.5,137.3,137.2,129.3,127.8,127.0,114.6,51.0$ ppm; IR (KBr) $v_{\max }=1690 \mathrm{~s}, 1449 \mathrm{~s}, 1410 \mathrm{~s}, 1201 \mathrm{~s} \mathrm{~cm}{ }^{-1} ; \mathrm{UV}\left(\mathrm{CH}_{2} \mathrm{Cl}_{2}\right) \lambda_{\max }=233(\log \varepsilon=3.46), 238 \mathrm{sh}$ (3.44), 256sh (3.32), 280 (3.46), 330 (3.83), 366sh (3.36), 399 (3.36), 543 (3.07), 564sh (3.06), 617 sh (2.72) $\mathrm{nm}$.

13. The X-ray data for $4: \mathrm{C}_{38} \mathrm{H}_{30} \mathrm{O}_{4}, \mathrm{Mw}=550.65,0.50 \times 0.30 \times 0.50 \mathrm{~mm}^{3}$, monoclinic, space group $P 2{ }_{1} / n$ (\#14), $a=21.222(2), b=13.4566(9), c=10.141(1) \AA, \beta=89.65(1) \mathrm{deg}, V=$

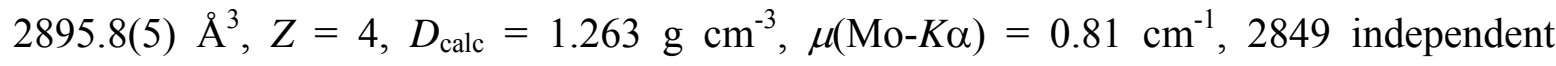
reflections, 388 parameters, $R=0.066, w R=0.087, \mathrm{~T}=298{ }^{\circ} \mathrm{K}$. Those for 8 : $\mathrm{C}_{38} \mathrm{H}_{30} \mathrm{O}_{6}, \mathrm{Mw}$ $=528.65,0.30 \times 0.30 \times 0.30 \mathrm{~mm}^{3}$, triclinic, space group P1(\#2), $a=8.679(1), b=11.496(1)$, $c=7.835(1) \AA, \alpha=95.28(1), \beta=108.56(1), \gamma=82.80(1) \mathrm{deg}, V=734.0(2) \AA^{3}, Z=1, D_{\text {calc }}$

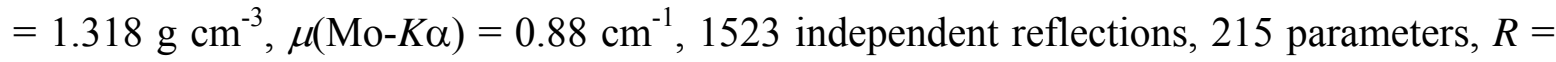
$0.052, w R=0.066, \mathrm{~T}=298{ }^{\circ} \mathrm{K}$. Estimated standard deviations for the bond lengths and angles are 0.004-0.007 (ang) and 0.2-0.4 (deg), respectively, for the non-hydrogen atoms. Crystallographic data excluding structures have been deposited with the Cambridge Crystallographic Data Centre as supplementary publication numbers CCDC 658455 for 4 and CCDC 658456 for 8, respectively. A copy of the data can be obtained free of charge from CCDC, 12 Union road, Cambridge CB2 1EZ. UK [DIRECT LINE: +44 1223 762910, Fax:+44 (0) 1223-336033 or e-mail: 1instead@ccdc.cam.ac.uk; deposit@ccdc.cam.ac.uk.

14. Bending angles of the benzene ring in X-ray structure of tetradehydro[2.2]paracyclophane at ambient temperature were $13.7^{\circ}$ for $\alpha\left(=\alpha^{\prime}\right)$ and $15.2^{\circ}$ for $\beta\left(=\beta^{\prime}\right)$; de Meijere, A.; Kozhushkov, S. I.; Rauch, K.; Schill, H.; Verevkin, S. P.; Kümmerlin, M.; Beckhaus, H.-D.; Rüchardt, C.; Yufit, D. S. J. Am. Chem. Soc. 2003, 125, 15110-15113. Bending angles in 
the calculated structures of $\mathbf{2}$ and 3 are as follows; $9.5^{\circ}$ for $\alpha\left(=\alpha^{\prime}\right)$ and $5.8^{\circ}$ for $\beta\left(=\beta^{\prime}\right)$ in $\mathbf{2}$, and $8.5^{\circ}$ for $\alpha \alpha\left(=\alpha^{\prime}\right)$ and $4.7^{\circ}$ for $\beta\left(=\beta^{\prime}\right)$ in 3 .

15. For deformations of azulenes, see following recent papers and references in there; a) Yamamura, K.; Kawabata, S.; Kimura, T.; Eda, K.; Hashimoto, M. J. Org. Chem. 2005, 70, 8902-8906; b) Ohta, A.; Thanh, N. C.; Terasawa, K.; Fujimori, K.; Kuroda, S.; Oda, M. Tetrahedron Lett. 2006, 47, 2815-2819.

16. The twist angles were obtained by the way reported in the following reference; Symth, N.; Van Eugen, D.; Pascal, Jr., R. A. J. Org. Chem. 1990, 55, 1937-1940. 